\title{
Poaceae, Secale spp. and Artemisia spp. pollen in the air at two sites of different degrees of urbanisation
}

\author{
Aleksandra Kruczek ${ }^{1,2}$, Małgorzata Puc ${ }^{1,2}$, Tomasz Wolski ${ }^{3}$ \\ ${ }^{1}$ Faculty of Biology, Department of Botany and Nature Conservation, University of Szczecin, Poland \\ ${ }^{2}$ Centre for Molecular Biology and Biotechnology, University of Szczecin, Szczecin, Poland \\ ${ }^{3}$ University of Szczecin, Coastal Marine Hydrography Unit, Institute of Marine and Coastal Sciences, Department of \\ Geosciences
}

Kruczek A, Puc M, Wolski T. Poaceae, Secale spp. and Artemisia spp. pollen in the air at two sites of different degrees of urbanisation. Ann Agric Environ Med. 2017; 24(1): 70-74. doi: 10.5604/12321966.1233895

\begin{abstract}
Introduction. Among herbal plants, most cases of allergic reactions, like seasonal inflammation of nasal mucosa, conjunctivitis and pollen asthma, are related to the allergens from grass pollen. As the blossoming and pollination of rye is known to start the pollen season of grasses, information about the airborne rye pollen count permits alerting the people allergic to certain allergens contained in rye pollen. An important cause of allergy is also the pollen from wormwood, blossoming in late summer, as its two main allergens produce cross-reactions with many other plant allergens.

Objective. The aim of the study was to evaluate the risk of allergic reactions in persons with pollinosis on the basis of the pollen calendar, analysis of concentrations of pollen grains of grass and rye, and comparison of diurnal pattern of airborne pollen grain concentrations at two sites with different degrees of urbanisation (Gudowo in the country and the city of Szczecin) in 2012-2014.

Materials and methods. The concentration of pollen was measured by the volume method. Length of the pollination season was determined by the method of $98 \%$, assuming that the beginning and the end of the pollen season are the days on which $1 \%$ and $99 \%$ of the annual sum of pollen appeared.

Results. The first pollen grains to appear in the air are those produced by rye, followed by those produced by grass and wormwood. The pollen seasons of grasses and wormwood started about one week earlier in Gudowo than in Szczecin, while the pollen season of rye started at almost the same time in the country and in the city. Airborne pollen counts of grasses, rye and wormwood were much higher in the country than in the city. The differences most probably result from the different floristic composition at these two sites and reflect the local contribution of the taxa studied in the country. Conclusions. The risk of allergy caused by the pollen of the taxa analysed was much higher in Gudowo (in the country), than in Szczecin city.
\end{abstract}

Key words

aerobiology, allergy, pollen count, Poaceae, Secale, Artemisia

\section{INTRODUCTION}

Allergy, which is a reaction by the immune system to something in the environment that causes no problems forost people, has become a social disease [1]. It affects $25-35 \%$ of the human population; in Poland, it occurs in about $20 \%$ of inhabitants [2]. One of the most frequent causes of allergy in Poland [3] and in Europe [4] is plant pollen. The social effect of allergy is illustrated by the fact that the allergy sufferers were the first in the history of medicine to form mutual support groups, which in the 19th century was exceptionally rare [5].

From among herbal plants, most cases of allergic reactions, like seasonal inflammation of nasal mucosa, conjunctivitis and pollen asthma, are related to the allergens from grass pollen $[6,7,8,9]$. On the basis of structural similarities, about a dozen groups of grass pollen allergens are distinguished [10], among them profilins, whose allergy producing properties are associated with the degree of air pollution. Profilins can also be responsible for the cross- reaction between the

Address for correspondence: Aleksandra Kruczek, University of Szczecin, Faculty of Biology, Department of Botany and Nature Conservation

E-mail: aleksandra.kruczek@univ.szczecin.pl

Received: 7 November 2015; accepted: 16 February 2016; first published on January 2017 allergens of grass pollen and edible vegetables $[6,8,11]$. The diurnal count of airborne grass pollen grains reach very high values [12], and the period of grass blossoming lasts from May - October, a long period of time [13]. The first symptoms of allergy (running nose, itching and sneezing, reddening and watering of the eyes) appear at the exposure to 20 grass pollen grains in $1 \mathrm{~m}^{3}$ of air [14]. A characteristic feature distinguishing the pollen grains of the plants from Poaceae family is their clearly elliptical shape [15]. Precise distinction of pollen grains produced by particular grass species is impossible $[6,11,15]$. As the blossoming and pollination of rye is known to start the pollen season of grasses, information on the airborne rye pollen count permits alerting the people allergic to certain allergens contained in the rye pollen, e.g. secalines from the group of prolamines [16].

An important cause of allergy is also the pollen from wormwood, blossoming in late summer, as its two main allergens Art v I and Art v II produce cross-reactions with many other plant allergens [17]. The wormwood pollen grain concentrations reach very high values, often over 400 pollen grains in $1 \mathrm{~m}^{3}$ of air [18]. The first symptoms of pollinosis are observed at a concentration of about 30 pollen grains in $1 \mathrm{~m}^{3}$ of air [14]. The persons allergic to wormwood pollen display the clinical complexes: wormwood -celery- 
spices and wormwood-mustard [11, 17, 19]. The wormwood pollen can produce not only inflammation of nasal mucosa, conjunctivitis or pollen asthma but also on contact skin, eruptions appearing when the skin (mostly of the face and hands) is exposed to wormwood pollen [20].

\section{OBJECTIVES}

The aim of the study was to evaluate the risk of allergic reactions in persons with pollinosis on the basis of the pollen calendar, analysis of concentrations of pollen grains of grass and rye, and comparison of diurnal patterns of airborne pollen grain concentrations at two sites with different degrees of urbanisation (country and city) in 2012-2014.

Comparative analysis of the risk of allergy in the areas with different degrees of urbanisation are unique in Poland, while analysis of the diurnal pattern of airborne pollen grain concentration in the city and in the country have not been performed to-date.

\section{MATERIALS AND METHODS}

Aeropalynological measurements were performed by the volumetric method, using the instruments VST Burkard and VPPS Lanzoni 2000, in the way recommended by the International Association for Aerobiology (IAA). Samples of aeroplankton were collected in 2012-2014 at two sites with different degrees of urbanisation: in the city of Szczecin and in the village Gudowo, West Pomerania. The volumetric instruments collect air samples of the volume corresponding to the average lung capacity of humans and permit determination of the pollen concentration in $1 \mathrm{~m}^{3}$ per $24 \mathrm{~h}$, and at every hour.

The pollen produced by the following taxa was analysed: Poaceae, Secale spp. and Artemisia spp. The length of the pollination season was determined by the method of $98 \%$ [21], assuming that the beginning and the end of the pollen season are the days on which $1 \%$ and $99 \%$ of annual sum of pollen appeared. The pollen season abundances were compared on the basis of the Seasonal Pollen Index (SPI), which is the sum of the mean diurnal pollen concentrations in a given season [22]. The dynamics of the seasons were illustrated by determination of the phases of pollen seasons [23]: phase 1) beginning of the season on the day when $1 \%$ of the annual sum of pollen appeared, phase 2) $2.5-5 \%$, phase 3) $5-25 \%$, phase 4) 25-50\%, phase 5) $50 \%$, phase 6) $50-75 \%$, phase 7) 75-95\%, phase 8) 95-97.5\%, and phase 9) end of the season for $99 \%$ of the annual pollen sum. On the basis of literature data, the number of days with the pollen concentration equal to or exceeding the threshold value (defined as that at which the first symptoms of pollinosis appear) were determined. The concentrations of pollen grains of grass, rye and wormwood were also measured at every hour.

The effect of the weather elements, and for Szczecin also the effect of air pollution on the pollen count, was analysed. Statistical analysis was performed and Spearman's rank correlation coefficient was calculated [24].

\section{RESULTS}

In a given season, the first to appear in the air were the pollen grains of rye, followed by those of grasses and wormwood. For the longest time, the pollen grains of grasses remained in the air, on average, for 124 days in Szczecin and 118 days in Gudowo. The pollen season of wormwood lasted, on average, for 87 days in Szczecin and over a week longer in Gudowo. The shortest was the pollen season of rye which lasted, on average, 36 days in Gudowo and nearly two weeks longer in Szczecin. The pollen seasons of grasses and wormwood started by about one week earlier in Gudowo than in Szczecin, while the pollen season of rye started at almost the same time in the country and in the city. The concentrations of pollen grains of the taxa analysed were much higher in Gudowo than in Szczecin. The annual sums of concentrations and the maximum concentrations were from 1.5-3 times higher in the country. At both sites studied, the peak of the pollen season of rye was in May, grasses in June, and wormwood in August.

Evaluation of the threat caused by allergens from the pollen of grasses and wormwood was made on the basis of pollen calendars, (Fig. 1; Tab. 1). The threat by pollen allergens from

Table 1. Characteristics of pollen seasons of Poaceae, Secale spp. and Artemisia spp. in Szczecin (S) and Gudowo (G) in 2012-2014. Threshold pollen counts according to Rapiejko et al. [14]

\begin{tabular}{|c|c|c|c|c|c|c|c|c|c|c|}
\hline & \multicolumn{3}{|c|}{ Poaceac } & \multicolumn{3}{|c|}{ Secale } & \multicolumn{3}{|c|}{ Artemisia } \\
\hline & & 2012 & 2013 & 2014 & 2012 & 2013 & 2014 & 2012 & 2013 & 2014 \\
\hline \multirow{2}{*}{ Start } & & $14 \mathrm{~V}$ & $21 \mathrm{~V}$ & $\overline{11 \mathrm{~V}}$ & $3 \mathrm{~V}$ & $20 \mathrm{~V}$ & $21 \mathrm{~V}$ & $12 \mathrm{VII}$ & $10 \mathrm{VI}$ & $2 \mathrm{VI}$ \\
\hline & G & $21 \mathrm{~V}$ & $16 \mathrm{~V}$ & $17 \mathrm{~V}$ & $9 \mathrm{~V}$ & $20 \mathrm{~V}$ & $20 \mathrm{~V}$ & $8 \mathrm{VI}$ & $12 \mathrm{VI}$ & $5 \mathrm{VI}$ \\
\hline \multirow{2}{*}{ End } & s & $16 \mathrm{IX}$ & $14 \mathrm{LX}$ & $14 \mathrm{LX}$ & $26 \mathrm{VI}$ & $2 \mathrm{VIII}$ & $6 \mathrm{Vl}$ & $14 \mathrm{IX}$ & $8 \mathrm{IX}$ & $15 \mathrm{IX}$ \\
\hline & G & $13 \mathrm{dx}$ & $11 \mathrm{dx}$ & $12 x$ & $30 \mathrm{Vl}$ & $19 \mathrm{Vl}$ & $13 \mathrm{Vl}$ & $91 \mathrm{X}$ & $10 \mathrm{Lx}$ & $13 \mathrm{DX}$ \\
\hline \multirow{2}{*}{ Length/days } & s & 129 & 117 & 127 & 55 & 75 & 17 & 65 & 91 & 106 \\
\hline & G & 116 & 119 & 119 & 53 & 31 & 25 & 94 & 91 & 101 \\
\hline \multirow{2}{*}{ Maximum } & $\mathrm{s}$ & 133 & 151 & 326 & 5 & 8 & 11 & 57 & 54 & 33 \\
\hline & G & 368 & 180 & 503 & 17 & 21 & 24 & 103 & 121 & 71 \\
\hline \multirow{2}{*}{ Date of maximum } & s & $14 \mathrm{~V}$ & $18 \mathrm{~V}$ & $9 \mathrm{~V}$ & $25 \mathrm{~V}$ & $31 \mathrm{~V}: 3 \mathrm{VI}$ & $27 \mathrm{~V}$ & $13 \mathrm{VIII}$ & $10 \mathrm{VI}$ & $29 \mathrm{VII}$ \\
\hline & G & $8 \mathrm{VI}$ & $9 \mathrm{VI}$ & $9 \mathrm{VI}$ & $27 \mathrm{~V}$ & $15 \mathrm{Vl}: 31 \mathrm{~V}: 3 \mathrm{VI}$ & $27 \mathrm{~V}$ & 2 VIII & $3 \mathrm{VIII}$ & $9 \mathrm{VIII}$ \\
\hline \multirow{2}{*}{ SPI } & s & 2228 & 3155 & 4483 & 52 & 60 & 54 & 519 & 689 & 647 \\
\hline & G & 3751 & 3172 & 5796 & 103 & 108 & 139 & 861 & 860 & 1066 \\
\hline Month with maximum & s & vi & vi & VI & $\mathrm{v}$ & $\mathrm{VI}$ & $\mathrm{v}$ & VIII & VIII & VIII \\
\hline & G & VI & VII & VI & v & $\mathrm{VI}$ & v & VIII & VIII & VIII \\
\hline Threshold pollen count & & & 20 & & & 20 & & & 30 & \\
\hline Days > threshold pollen & s & 39 & 49 & 53 & 0 & 0 & 0 & 3 & 3 & 4 \\
\hline count & G & 43 & 49 & 53 & 0 & 2 & 2 & 10 & 6 & 11 \\
\hline
\end{tabular}

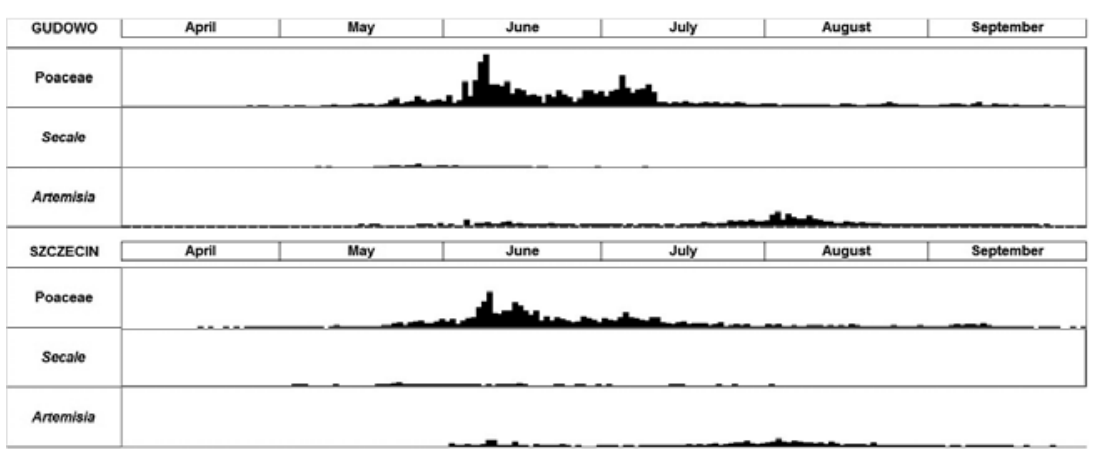

Figure 1. Pollen calendars for Gudowo and Szczecin in 2012-2014 


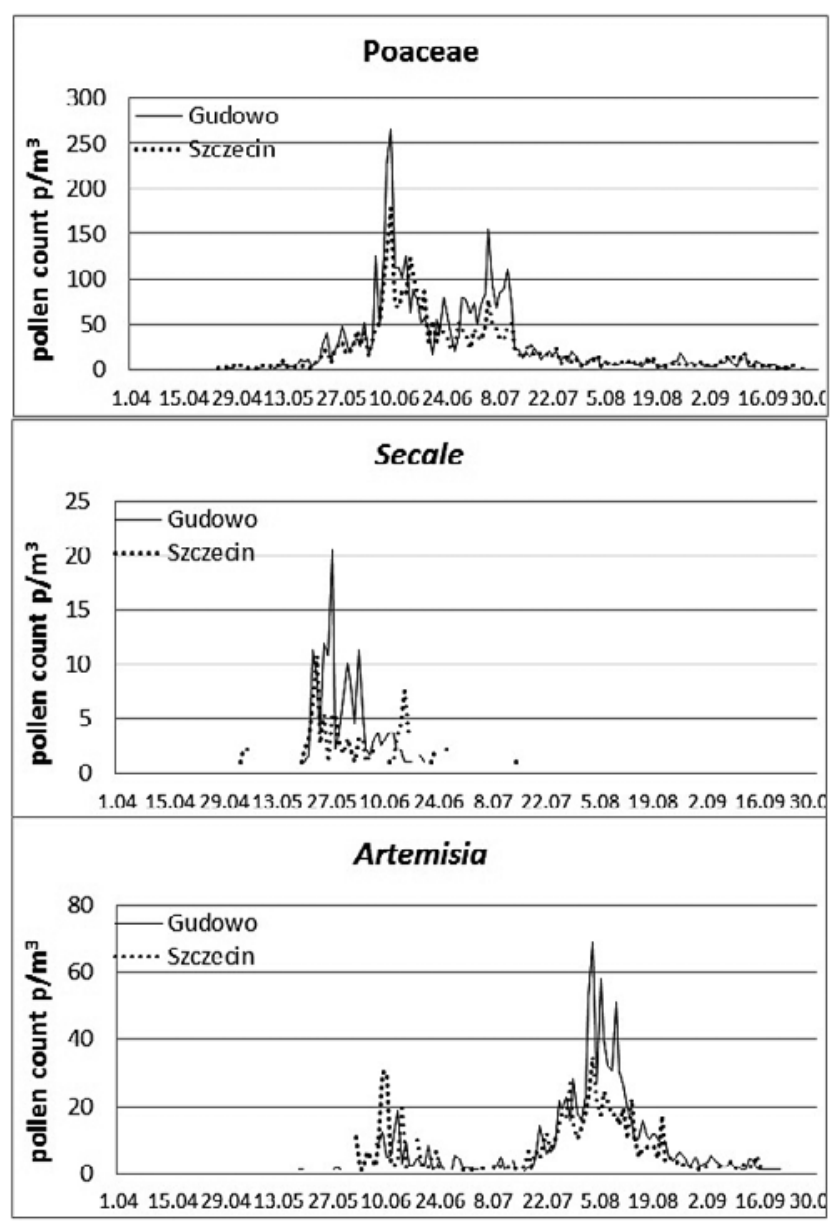

Figure 2. Mean course of pollen seasons of Poaceae, Secale spp. and Artemisia spp. in Gudowo and Szczecin in 2012-2014

grasses and wormwood was higher in the country. In 2012 -2014 , the grass pollen grain concentrations higher than the threshold values were noted in Gudowo, on average, for 48 days, in Szczecin for 47 days, while those of wormwood pollen grains, on average, for 9 days in Gudowo and 3 days in Szczecin.

The percentage contribution of grass pollen grains in SPI of the taxa studied was the highest and equal to $80 \%$ in Gudowo and $82 \%$ in Szczecin. The contribution of wormwood pollen grains varied from $16 \%$ in Szczecin to $18 \%$ in Gudowo. The lowest was the contribution of rye pollen grains, reaching $1.5 \%$ in Szczecin to 2\% in Gudowo. The pollen seasons of herbal plants (Fig. 2) in the country and in the city were characterised by alternate periods of increased and decreased concentrations of pollen grains.

In order to compare the dynamics of pollen seasons [23] of the herbal plant taxa studied in Gudowo and Szczecin (Fig. 3), 9 phases of pollen seasons were distinguished according to selected values of percentage of the annual pollen sum. In the pollen season of grasses in Gudowo, the dominant was phase 6 in which the airborne pollen concentration reached $50-75 \%$ of the annual sum, while in Szczecin the longest was phase 7 in which the analogous concentration reached $75-95 \%$ of the annual sum. In both localities, the longest in the rye pollen season was phase 7, while the longest in the wormwood pollen season was phase $3(5-25 \% \mathrm{SPI})$.

The airborne pollen count shows a diurnal pattern of changes (Fig. 4). In both localities, 2 maxima in the diurnal pattern of grass pollen count changes were observed, one

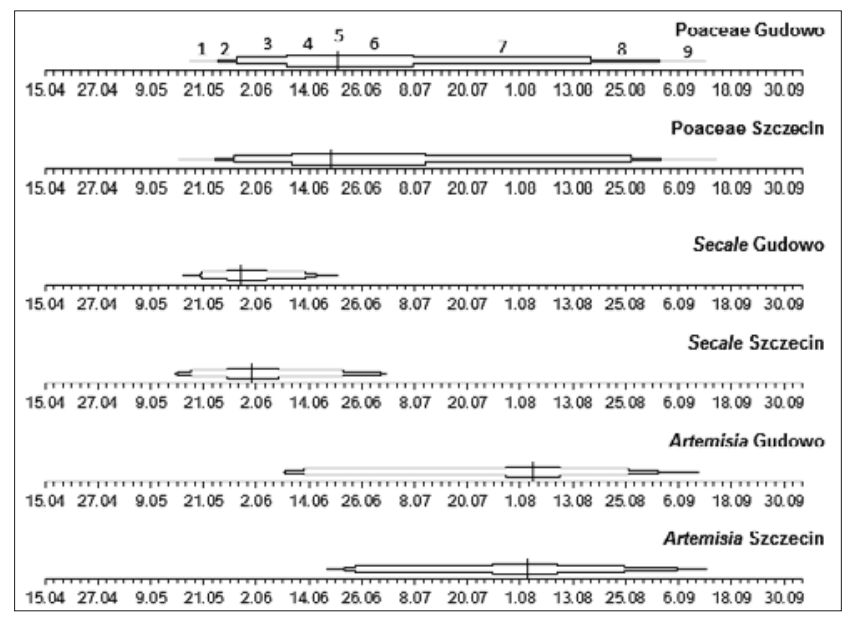

Figure 3. Dynamics of pollen seasons of Poaceae, Secale spp. and Artemisia spp. Phase of seasons: 1) beginning of season for $1 \%$ of annual total pollen; 2 ) $2.5-5 \%$; 3) $5-25 \%$; 4) $25-50 \%$; 5) $50 \%$ (vertical line); 6) 50-75\%; 7) 75-95\%; 8) 95-97.5\%; 9) end of season for $99 \%$ of the annual total pollen
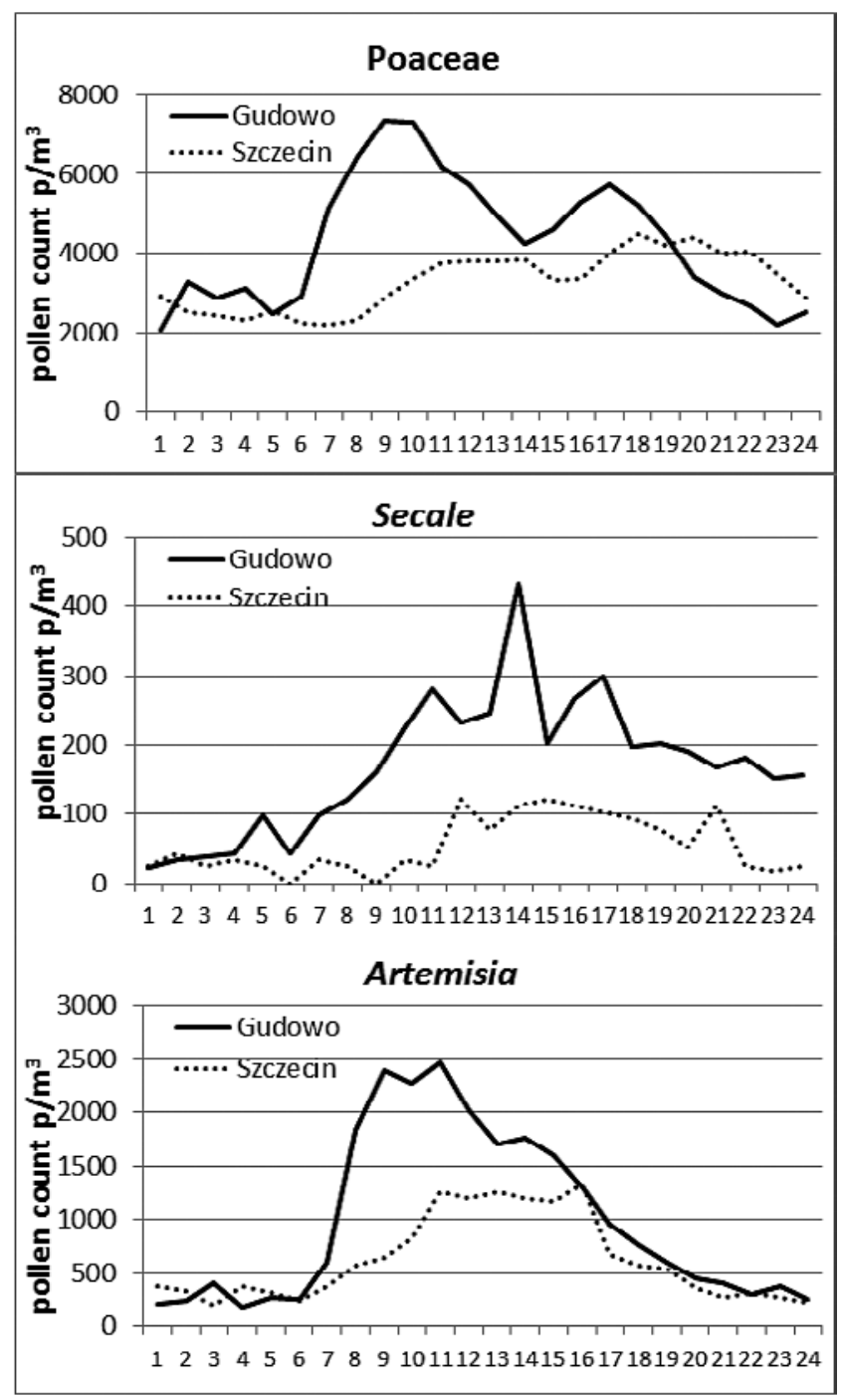

Figure 4. Diurnal pattern of hourly distribution of pollen count of Poaceae, Secale spp. and Artemisia spp. in Gudowo and Szczecin in 2012-2014

before noon and one in the afternoon. The maximum grass pollen count in Gudowo was noted during 09.00-10.00 and 16.00-18.00, while in Szczecin from 18.00-20.00. The pollen 
Table 2. Spearman's rank correlation coefficients between mean daily pollen level and selected meteorological parameters in Gudowo

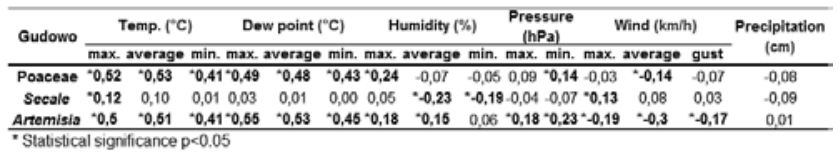

Table 3. Spearman's rank correlation coefficients between mean daily pollen level and selected meteorological parameters and air pollution data in Szczecin

\begin{tabular}{|c|c|c|c|c|c|c|c|c|c|c|c|c|c|c|c|c|c|}
\hline \multirow{2}{*}{ Szczecin } & \multicolumn{3}{|c|}{ Temp. $\left({ }^{\circ} \mathrm{C}\right)$} & \multirow{2}{*}{$\begin{array}{r}\text { Dew } \\
\text { - point } \\
\left({ }^{\circ} \mathrm{C}\right) \\
\end{array}$} & \multirow{2}{*}{$\begin{array}{c}\text { Humidity } \\
(\%)\end{array}$} & \multirow{2}{*}{$\begin{array}{c}\text { Pressure } \\
(\mathrm{hPa})\end{array}$} & \multicolumn{2}{|c|}{ Wind $(\mathrm{m} / \mathrm{s})$} & \multirow{2}{*}{$\begin{array}{c}\text { Precipi } \\
\text { - tation } \\
\text { (mm) }\end{array}$} & \multirow{2}{*}{$\begin{array}{c}\text { Visibility } \\
\text { (km) }\end{array}$} & \multirow{2}{*}{$\begin{array}{c}\mathrm{SO}_{2} \\
\left(\mu \mathrm{g} / \mathrm{m}^{3}\right)\end{array}$} & \multirow{2}{*}{$\begin{array}{c}\mathrm{NO} \\
\left(\mu \mathrm{g} / \mathrm{m}^{3}\right)\end{array}$} & \multirow{2}{*}{$\begin{array}{c}\mathrm{NO}_{2} \\
\left(\mu \mathrm{g} / \mathrm{m}^{3}\right) \\
\end{array}$} & \multirow{2}{*}{$\begin{array}{c}\mathrm{O}_{3} \\
\left(\mu \mathrm{g} / \mathrm{m}^{3}\right) \\
\end{array}$} & \multirow{2}{*}{$\begin{array}{c}\mathrm{NO}_{x} \\
\left(\mu \mathrm{g} / \mathrm{m}^{3}\right) \\
\end{array}$} & \multirow{2}{*}{$\begin{array}{r}\mathrm{PM}_{10} \\
\left(\mu \mathrm{g} / \mathrm{m}^{3}\right) \\
\end{array}$} & \multirow{2}{*}{$\begin{array}{c}\mathrm{CO} \\
\left(\mu \mathrm{g} / \mathrm{m}^{3}\right)\end{array}$} \\
\hline & $\max$. & average & $\min$. & & & & $\max$. & average & & & & & & & & & \\
\hline Poaceae & ${ }^{*} 0,56$ & ${ }^{*} 0,53$ & ${ }^{*} 0,46$ & ${ }^{*} 0,42$ & ${ }^{*}-0,20$ & ${ }^{*} 0,13$ & $-0,02$ & $-0,02$ & ${ }^{*}-0,12$ & ${ }^{*} 0,22$ & ${ }^{*}-0,13$ & ${ }^{*}-0,16$ & ${ }^{*}-0,36$ & ${ }^{*} 0,13$ & ${ }^{*}-0,34$ & ${ }^{*}-0,10$ & $-0,04$ \\
\hline Secale & 0,03 & 0,04 & $-0,01$ & $-0,04$ & $-0,13$ & $-0,03$ & ${ }^{\circ} 0,09$ & 0,07 & $-0,05$ & ${ }^{\circ} 0,13$ & $-0,02$ & $-0,10$ & $-0,10$ & 0,07 & $-0,11$ & $-0,02$ & $-0,11$ \\
\hline Artemisia & ${ }^{*} 0,56$ & ${ }^{*} 0,51$ & ${ }^{*} 0,52$ & ${ }^{*} 0,53$ & $-0,04$ & ${ }^{*} 0,12$ & $-0,08$ & $-0,08$ & 0,02 & 0,03 & ${ }^{*}-0,15$ & 0,05 & ${ }^{*}-0,10$ & 0,00 & $-0,06$ & 0,03 & $-0,01$ \\
\hline
\end{tabular}

* Statistical significance $p<0.05$

count of rye reached the highest values at about noon. As for the wormwood pollen count, both in the country and in the city, it was high from before noon until about 16:00. The skewness coefficient for the diurnal pattern of grass pollen count in Szczecin was -0.06 which points to the left-side asymmetry of the distribution pattern, while the values of this coefficient calculated for rye and wormwood pollen count are higher than zero. Kurtosis of the diurnal pattern of rye pollen count in Gudowo of 0.63 , points to a greater concentration of results around the average value, than would follow from the normal distribution. In all other cases, the concentration of results around the average was smaller than in the normal distribution, kurtosis less than zero.

The airborne pollen count from the taxa Poaceae, Secale and Artemisia was analysed against the meteorological parameters and air pollution data (Tab. 2, 3). It was found that the pollen counts of grasses and wormwood increased with increasing minimum, mean and maximum temperature and increasing dew point. A negative correlation was deduced between the grass pollen count and the majority of air pollution parameters.

\section{DISCUSSION}

Grass pollen allergens in a moderate climate pose the greatest threat in summer when the period of grass blooming is very long [13]. In central Europe, the grass pollen season starts from the second half of May and lasts until the middle of July, whereas in northern Europe, it starts from the second half of June and lasts until the middle of August, and in southern Europe and the Mediterranean region it lasts through May [25]. In the years of study, the maximum grass pollen count in the season, both in Szczecin and Gudowo, was in June.

The maximum wormwood pollen count in Gudowo was noted in the first half of August. The second half of August has been indicated as the period of maximum grass pollen count representative for Poland [26]. Also, the maximum SPI for wormwood in Gudowo and in Szczecin were noted in August.

According to Kasprzyk [27], who compared the pollen count values in the country and in the cities, the airborne mean pollen count values for Poaceae, Plantago, Rumex and Urtica were higher in the country. Similar observations were made in the current study on the basis of airborne pollen count of grasses, rye and wormwood. Particular values of pollen count changed in the years, but were always higher in the country.

The values of airborne pollen count of herbal plants depended on the height at which the measuring instrument was mounted. The volumetric instruments mounted at 15$25 \mathrm{~m}$ above ground level permitted obtaining mean values for large areas, but the representation of pollen grains of low plants in the aeroplankton was significantly decreased. The results of measurements also depended on the location of the instrument [28]. In Gudowo, the measuring instrument was at a height of about $4.5 \mathrm{~m}$ in a garden, near a lawn, meadows and greenery. In Szczecin, the measuring instrument was placed at $21 \mathrm{~m}$ above ground level, on the roof of the Faculty of Biology at the University in the city.

The content of pollen grains in the air changed during the day, which was related to the time of the opening characteristic of a given species and, to a lower degree, with the temperature changes in the day [29]. On sunny days, the majority of wild grass species open their theca in the morning, between 06.30 - 07.30, and then in the afternoon between 17.00-19.00 [29]. There were 2 periods of elevated grass pollen count in the day, one before noon and one in the afternoon, which was particularly well seen in Gudowo. In the centre of Szczecin, far from blooming plants, the highest grass pollen count was usually noted in the afternoon [11]. Dowing [30] and Takehashi et al. [31] have reported that the flowers (and thus also the theca) of different species of grass open at different times of the day, e.g. the flowers of Dactylis glomerata open from 01.00-10.30, those of Lolium perenne from 08.00-16.00, and those of Poa pratensis usually at night, from 21.00-05.00, or sometimes also during the day, from 06.00-16.00. In the presented study, the highest rye pollen count was noted near noon, similar to the time reported by Dorofeev et al. [32]. During the day, the highest wormwood pollen count occurred before noon $[33,34]$; however, according to the current results, it lasted until the afternoon.

The effects of weather elements on airborne pollen count and the dynamics of pollen distribution can be different. Direct influence of weather elements is analysed by determination of correlations between the meteorological parameters and diurnal changes in the airborne pollen count [35]. According to the current results, the maximum, average and minimum temperatures of the air and dew point showed the strongest correlations to the pollen count values, while the influence of air humidity and precipitations was less significant. A positive correlation of the airborne pollen count of wormwood and grasses with increasing temperature is in agreement with the earlier results reported by e.g. BartkováŠčevková [36]. The air humidity and temperature influence the pollen release and transportation $[35,37]$. Dry and warm weather is conducive to the maturation of pollen grains in 
theca; therefore, the pollen count increases [36], while it decreases with decreasing temperature and on precipitations [38], which was clearly noted for the grass pollen count in Szczecin. Individual grass species begin emitting pollen at a specific temperature, air humidity $[39,40]$ at a specific level of precipitations and length of day, while the synoptic conditions, velocity and wind direction influence the duration and intensity of pollination [41]. The observations in the presented study revealed a negative effect of wind velocity on the wormwood pollen count in Gudowo.

In Poland, most often the cause of allergic inflammation of nasal mucosa and conjunctivitis is the sensitivity to allergens of pollen produced first by grasses [6], then birch tree and wormwood $[6,17]$. The correlation of clinical symptoms with the airborne pollen count is very strong [17]. The values of airborne pollen count from herbal plants depend on the local floristic composition, weather conditions, climate, geographical conditions, and the degree of urbanisation of a given area [27].

\section{CONCLUSIONS}

1. The length and intensity of pollen seasons of particular taxa at the 2 measuring sites were different. They depended on the actual localisation in the country and in the city, and on the habitat and weather conditions.

2. Airborne pollen counts of grasses, rye and wormwood were much higher in the country than in the city. The differences most probably resulted from the different floristic composition at these 2 sites, and reflect the local contribution of the taxa studied in the country.

3. The diurnal pattern of the airborne pollen count of grasses, rye and wormwood in Szczecin and Gudowo, was similar. The highest risk of developing allergic reaction was between 09.00 and 20.00 .

\section{REFERENCES}

1. Obtułowicz K. Alergia pyłkowa. Wyd. Polskie Towarzystwo Zwalczania Chorób Alergicznych (Kraków). 1993.

2. Hofman T, Michalik J. Alergia Pyłkowa. Wyd. TotalDruk (Poznań). 1998.

3. Arcimowicz M, Samoliński B, Zawisza E. Analiza częstości występowania dodatnich testów skórnych na wybrane alergeny pochodzenia roślinnego. Pyłki i Pyłkowica: Aktualne problemy. Instytut Medycyny Wsi w Lublinie 1995; 47.

4. D'Amato G, Spieksma FT, Liccardi G. Pollen-related allergy in Europe. Allergy 1998; 53: 567-578.

5. Dybova-Jahowicz S, Sadowska A. Palinologia. Wyd. Instytutu Botaniki PAN (Kraków), 2003.

6. Rapiejko P, Weryszko-Chmielewska E. Pyłek traw. Alergia Astma Immunologia 1998; 3(4): 187-192.

7. Leuschner R, Christen H, Jordan P, Vonthein R. 30 years of studies of grass pollen in Basel (Switzerland). Aerobiologia. 2000; 16: 381-391.

8. Rapiejko P, Lipiec A. Pyłek traw - aerobiologia, charakterystyka alergenów i aspekt kliniczny. Alergoprofil. 2005; 2 (2): 40-49.

9. Puc M. Threat of allergenic airborne Grass pollen in Szczecin, NW Poland: the dynamics of pollen season, effect of meteorological variables and air pollution. Aerobiologia. 2011; 27: 191-202.

10. Andersson K, Lindholm J. Characteristic and immunobiology of grass pollen allergens. Int. Arch. Allergy Immunol. 2003; 130: 87-107.

11. Rapiejko P. Alergeny pyłku roślin. Alergia Astma Immunologia. 1997; 2(1): 9-18.

12. Lipiec A, Malkiewicz M, Maj J, Puc M, Myszkowska D, WeryszkoChmielewska E, et al. Stężenie pyłku traw w 2006 r. Alergoprofil. 2006; 2(3): 52-61.

13. Chłopek K, Malkiewicz M, Myszkowska D, Kasprzyk I, Puc M, Balwierz $\mathrm{Z}$, et al. Pyłek traw w powietrzu wybranych miast Polski w 2007 roku. Alergoprofil. 2007; 3(4): 43-49.
14. Rapiejko P, Stankiewicz W, Szczygielski K, Jurkiewicz D. Progowe stężenie pyłku roślin niezbędne do wywołania objawów alergicznych. Otolaryngologia Polska. 2007; (61)4: 591-594.

15. Hyde HA, Adams KE. An atlas of airborne pollen grains. London Macmillan. CO LTD. St Martin's press (New York). 1958.

16. Braiteneder H., Mills E. N. C., 2005. Molecular properties of food allergens. The Journal of Clinical Immunology 115(1) 14-23.

17. Rapiejko P, Weryszko-Chmielewska E. Pyłek bylicy. Alergia Astma Immunologia. 1999; 4(3): 139-142.

18. Rapiejko P. Pyłek roślin złożonych (chwasty). Alergia i Ty 1999; 2: 18-20.

19. Rapiejko P, Lipiec A. Wybrane aspekty alergii krzyżowej. Alergoprofil. 2006; 2(2): 11-15.

20. Rudzki E. Co ludzi uczula i jak tego unikać. Medycyna praktyczna (Kraków). 1998.

21. Emberlin J, Savage M, Woodman R. Annual variations in the concentrations of Betula pollen in the London area. 1961-1990. Grana.1993; 32: 359-363.

22. Comtois P. Statistical analysis of aerobiological data. In: Mandrioli P, Comtois P, Levizzani V, editors. Methods in Aerobiology. Pitagora Editrice Bologna, Bologna. 1998. p. 217-259.

23. Latałowa M, Miętus M, Urska A. Seasonal variations in the atmospheric Betula pollen count in Gdansk (Southern Baltic coast) in relation to meteorological parameters. Aerobiologia. 2002; 18: 33-43.

24. StatSoft, Inc., 2011. STATISTICA (data analysis software system), version 10. www.statsoft.com

25. Rapiejko P, Weryszko-Chmielewska E, Chłopek K, Kupryjanowicz M, Puc M, Domański K, et al. Stężenie pyłku traw w 2000 roku. Alergologia Współczesna 2000; 2(05): 13-15.

26. Rapiejko P, Zielnik-Jurkiewicz B, Myszkowska D, Buczyłko K, Wagner A, Puc M, et al. Analiza stężenia pyłku bylicy w wybranych miastach Polski w 2009 roku. Alergoprofil. 2009; 5(3): 43-46.

27. Kasprzyk I. Comparative study of seasonal and intradiurnal variation of airborne herbaceous pollen in urban and rural areas. Aerobiologia 2006; 22: 185-195.

28. Lipiec A, Chłopek K, Siergiejko Z, Weryszko-Chmielewska E, Malkiewicz M, Piotrowska K, et al. Analiza stężenia pyłku bylicy w wybranych miastach Polski w 2006 r. Alergoprofil 2007; 3(1): 44-50.

29. Tarkowski C. Biologia żyta. PWN (Warszawa), 1983.

30. Dowing P. Wind pollination mechanism and aerobiology. In: Giles KL, Prakash J, editors. Pollen, cytology and development. Academic Press, Orlando; 1987. p. 421-437.

31. Takehashi Y, Sakaguchi M, Inouye S, et al. Airborne grass pollen antigens in a grassland as studied by immunoblotting with anti-Ld p I antibody. Grana 1993; 32: 302-307.

32. Dorofeev VF, Łaptev JP, Čekalin NM. Cvetenie, opylenie i gibridizacia rastenij. Agropromizdat (Moskwa), 1990.

33. Weryszko-Chmielewska E. Sezonowa i dobowa zmienność zawartości pyłku bylicy (Artemisia L.) w powietrzu Lublina w latach 1995-2001. Annales UMCS 2002; EEE(X): 153-160.

34. Spieksma FThM, Corden JM, Detandt M, Millington WM, Nikkels H, Nolard N, et al. Quantitative trends in annual totals of five common airborne pollen types (Betula, Quercus, Poaceae, Urtica and Artemisia), at five pollen - monitoring stations in western Europe. Aerobiologia 2003; 19: 171-184.

35. Palacios I, Molina R, Rodriguez A. The importance of interactions between meteorogical conditions when interpreting their effect on the dispersal of pollen from homogeneously distributed sources. Aerobiologia. 2007; 23: 17-26.

36. Bartková-Ščevková J. The influence of temperaturę, relative humidity and rainfall on the occurrence of pollen allergens (Betula, Poaceae, Ambrosia artemisiifolia) in the atmosphere of Bratislava (Slovakia). Int J Biometeorol. 2003; 48: 1-5.

37. Piotrowska K, Weryszko-Chmielewska E. Pollen count of selected taxa in the atmosphere of Lublin using two monitoring methods. Ann Agric Environ Med. 2003; 10: 79-85.

38. Peternel R, Srnec L, Culig J, Zaninovic K, Mitic B, Vukusic I. Atmospheric pollen season in Zagreb (Croatia) and its relationship with temperature and precipitation. Int J Biometeorol. 2004; 48: 186-191.

39. Bochniarz J. Obserwacje nad biologią kwitnienia traw. Rocz. Nauk Roln. 1960; A(83): 177-202.

40. Rutkowska B. Badania prowadzone w Polsce w zakresie biologii traw. Post Nauk Roln. 1970; 5: 51-66.

41. Jones A, Harrison R. The Effects of Meteorological Factors on Atmospheric Bioaerosol Concentrations - A Review. School of Geography, Earth and Environmental Science the University of Birmingham Edgbaston, 2004. 